\title{
Pocket Surveying Buildings
}

\author{
Title: Pocket Surveying Buildings \\ Authors: Malcolm Hollis \\ Publisher: RICS Books, Coventry, UK \\ Publication Date: (2006) 2nd edn \\ ISBN: 978-1842-192429 \\ Details: Hardback, 243 pages
}

List Price: $£ 22.50$

Journal of Building Appraisal (2007) 3, 243-244. doi:10.1057/palgrave.jba.2950081

This is a revised and enlarged version of the first edition of this pocketbook, published in 2002.

The reason behind its publication was clearly set out in the blurb on the back of the first edition:

\begin{abstract}
'You are inspecting a property, miles away from your office and faced with a tricky problem. You wish you had Malcolm Hollis's "Surveying Buildings" with you but it is too heavy to carry. You need Pocket Surveying Buildings'.
\end{abstract}

This latest edition with 243 pages instead of the 600 pages of the latest edition of the 'parent' book is certainly small enough to be called a pocketbook.

A glance at the headings in the table of contents of the new pocketbook contents shows that it covers a very wide range of matter relevant to surveying buildings:

What is a survey? - The inspection - Reporting - Surveys of specialist buildings Surveying equipment - The contract - The duties of surveyors, their performance and breach - Health in buildings - Roofs - Walls - Sealants - Metals - Windows Floors - Surveying services - Dampness - Timber decay caused by insect attacks Rot and fungus damage to timber - Interpreting cracks - Common UK dwelling types and their defects - Summary - Index.

In the preface to this new edition, the author rightly points out that no book can be a substitute for practical experience. It can, however, be a salutary (and expensive) matter to gain practical experience solely by trial and error, particularly if it is a court of law that points out that error!

The best way for surveyors to learn the craft of surveying buildings is to learn the basics at college and then serve what amounts to an apprenticeship by accompanying and assisting experienced surveyors as they inspect a building. Of course, learning this way has to be augmented by ongoing reference to published material which, primarily, will be original sources such as the Digests and other papers published by the Building Research Establishment (BRE) and from papers in technical journals. (The Pocketbook, on page 13, gives a list of some of the publications that, it is suggested, the surveyor should have read.) In addition, during their careers, surveyors will keep up to date with current developments by attending talks and seminars as part of CPD. 
There is no doubt that, in addition to all of this, most surveyors will have read and frequently referred to one of the books published on the subject, particularly Malcolm Hollis's popular Surveying Buildings.

The question is, how much will it help to do this reading while at the property making a survey?

Clearly, in an ideal world, the result of all of this learning and study will be in surveyors' minds before arriving at a property, but there is big difference between having learnt something and being able to recall it on demand. Also, surveyors may come across problems that they have not met before and it is better, rather than guessing, to research a novel problem that had not been anticipated. Here this pocketbook is likely to be very useful.

The book, however, does more than help with previously unknown facts; it provides checklists to help to ensure that matters are not forgotten in the course of the inspection and enables the surveyor to adopt the most effective routine for the survey.

A possible criticism of the book is that it contains a lot of information that, although of considerable value to surveyors, is not relevant to what is needed at the property when making a survey. In the blurb on the back of the first edition of the pocketbook, it was suggested that it was either a stand-alone tool or a portable companion to the main work. Clearly, in the first role, all of the subjects in the text were relevant. This role for the book is not claimed for the second edition but, of course, its owners are free to use it in this way and, by referring to the table of contents and the index, no one should find it difficult to find the parts relevant to the survey that they are conducting.

This reviewer has had 30 years of acting as an expert when surveyors have been sued in the courts for alleged negligence when making condition surveys. It seemed a good idea to consider how reference to this book at the time of the inspection (if it had then been published!) might have helped the unfortunate surveyors in those cases where the findings of the court went against them. It was clear, from a mental review of these, that, in many of them, reference to this book would have helped to avoid their problems.

In general, this book will be of considerable assistance to surveyors, and not least to those who are well experienced - one cannot carry everything in one's head all the time. It would, however, be of little help to anyone who did not have sound basic training and experience to undertake such a survey.

In summary, this book is good value for money and would be a most useful tool for surveyors to have handy while making a condition survey of most types of domestic properties and also for many commercial and other types of building.

Ronald Wilde

Consultant

Wilde, Spooner Raleigh 